\title{
Development and population growth of Hydra viridissima Pallas, 1766 (Cnidaria, Hydrozoa) in the laboratory
}

\author{
Massaro, FC. ${ }^{\text {a* }}$ and Rocha, $O .^{\text {b }}$ \\ aPrograma de Pós-Graduação em Ciências da Engenharia Ambiental, Escola de Engenharia de São Carlos, \\ Universidade de São Paulo - USP, Av. Trabalhador Sancarlense, 400, CEP 13566-590, São Carlos, SP, Brazil \\ ${ }^{\text {b}}$ Departamento de Ecologia e Biologia Evolutiva, Universidade Federal de São Carlos - UFSCar, \\ Via Washington Luís, Km 235, CP 676, CEP 13565-905, São Carlos, SP, Brazil \\ *e-mail: fe_massaro@yahoo.com.br
}

Received May 15, 2006 - Accepted December 21, 2006 - Distributed May 31, 2008

(With 2 figures)

\begin{abstract}
Hydras, the most representative freshwater Cnidaria, are of common occurrence in bodies of water in every continent except Antarctica. This study was planned with the aim of maintaining a population of Hydra viridissima in laboratory culture to enable the determination of the individual and population growth-rates of this species, as well as its population doubling time and generation time, with a view to employing these common animals as test-organisms in ecotoxicological assays. The organisms were maintained in reconstituted water at $20 \pm 2{ }^{\circ} \mathrm{C}$, illuminated at 800 lux with a photoperiod of 12 hours light: 12 hours dark, and were fed on neonates of the cladoceran Ceriodaphnia silvestrii ( 3 or 4 neonates per hydra, 3 times a week). The individual growth-rate (k) of the species was 0.43 , the maximum length of the column $2.53 \mathrm{~mm}$ and the generation time $6.6 \pm 1.5$ days on average. The hydra population showed an intrinsic growth-rate (r) of 0.0468 , according to the fitted curve, and a doubling time of $14.8 \pm 2.63$ days. Hydra viridissima is easy to grow in the laboratory and performs well in the conditions used in this study. It is thus a promising candidate test-organism for ecotoxicological studies.
\end{abstract}

Keywords: freshwater Cnidaria, individual growth, population growth, culture of hydras, Hydra viridissima.

\section{Desenvolvimento e crescimento populacional de Hydra viridissima Pallas, 1766 (Cnidaria, Hydrozoa) em laboratório}

\begin{abstract}
Resumo
As hidras, os mais representativos Cnidaria de água doce, são organismos comuns em corpos de água doce de todos os continentes, exceto na Antártida. O objetivo do presente estudo foi manter o cultivo em laboratório da espécie Hydra viridissima, determinando-se o crescimento individual e populacional desta espécie, assim como seu tempo de duplicação da população e de geração, visando sua utilização como organismo-teste em ensaios ecotoxicológicos. Os organismos foram mantidos em água reconstituída, a uma temperatura de $20 \pm 2{ }^{\circ} \mathrm{C}$, com luminosidade de 800 lux e fotoperíodo de 12 horas luz/ 12 horas escuro, e foram alimentados com neonatas do Cladocera Ceriodaphnia silvestrii (3 a 4 neonatas por indivíduo). A taxa de crescimento individual (k) obtida foi de 0,43 , o comprimento máximo da coluna das hidras foi de 2,53 mm e o tempo de geração foi, em média, de 6,6 \pm 1,5 dias. A espécie apresentou uma taxa intrínseca de crescimento populacional (r) igual a 0,0468 para a curva ajustada e um tempo de duplicação da população de 14,8 \pm 2,63 dias. A espécie Hydra viridissima é de fácil cultivo em laboratório e apresentou um bom desempenho nas condições testadas, sendo, portanto, um potencial organismo-teste para estudos ecotoxicológicos.
\end{abstract}

Palavras-chave: Cnidaria de água doce, crescimento individual, crescimento populacional, cultivo de hidras, Hydra viridissima.

\section{Introduction}

The freshwater Cnidaria of São Paulo State, indeed of Brazil as a whole, are relatively little known in comparison with the members of this phylum in the USA or Europe, in spite of being common organisms in most freshwater habitats (Silveira and Schlenz, 1999).

In particular, hydras are common in bodies of water in every continent except Antarctica (Holstein, 1995).
They are strictly carnivorous, feeding mainly on small crustaceans, including cladocerans and copepods, insects and annelids. Asexual budding is the commonest means of reproduction (Pennak, 1953).

Only four species of Hydra (Class Hydrozoa, Subclass Anthomedusae, Family Hydridae) are known in Brazil: Hydra viridissima Pallas, 1766 (Cordero, 1939; 
Wolle, 1978), Hydra iheringi Cordero, 1939 (Cordero, 1939), Hydra intermedia Wolle, 1978 (Wolle, 1978) and Hydra salmacidis Silveira, Gomes and Silva, 1997 (Silveira et al., 1997).

Hydra viridissima (formely Chlorohydra viridissima) appears green, owing to its symbiotic relationship with the green alga, Chlorella vulgaris, which are present in the body of the hydra. The algae are found in vacuoles within the gastrodermal cells, where they are protected from host digestive enzymes (Muscatine, 1974). Up to 20 algal cells may coexist in the same animal cell (Douglas, 1995). The photosynthetic alga supplies nutrients such as maltose (Muscatine, 1965) or glucose-6-phosphate (Lenhoff and Muscatine, 1963; Roffman and Lenhoff, 1969; Kelty and Cook, 1976) to the hydra.

When hydras are exposed to toxic substances, they may undergo graded changes in their body structure, which can be used as indicative of the degree of toxicity to be assayed at lethal or sublethal concentrations. Moreover, these organisms are present in a variety of freshwater environments, are easy to culture and maintain in the laboratory, reproduce rapidly and can be used in toxicity tests that are both simple to perform and lowcost (Trottier et al., 1997). Hydra viridissima makes a very promising candidate test-organism for ecotoxicological research, so, the objective of the present study was to measure basic demographic parameters of population growth under controlled conditions in the laboratory, since these characteristics are fundamental to the development of standardized ecotoxicological tests.

\section{Material and Methods}

Examples of the species Hydra viridissima were collected from outdoor concrete tanks in the Experimental Reserve of the Department of Ecology and Evolutionary Biology at the Federal University of São Carlos (SP, Brazil).

The hydras were cultured in circular glass aquaria, $20 \mathrm{~cm}$ in diameter, in reconstituted water (ABNT, 2004). The cultures were kept at $20 \pm 2{ }^{\circ} \mathrm{C}$, under a light source of 800 lux, with a photoperiod 12 hours light: 12 hours dark. Three times a week, 3 or 4 neonates of the cladoceran Ceriodaphnia silvestrii per hydra were supplied as food. The water was changed and the culture cleaned twice a week.

In both the population and individual growth experiments, the hydras were maintained under the same culture conditions, with 10 replicates for each test, but in the individual growth experiment only the individuals of seven replicates had survived until the end of the experiment.

Hydra specimens were placed in non-toxic plastic transparent recipients of $250 \mathrm{~mL}$ capacity with $100 \mathrm{~mL}$ of reconstituted water, in replicates. Experiments were run at the temperature of $20 \pm 2{ }^{\circ} \mathrm{C}$, in a temperature controlled room, 800 lux illumination and 12 hours light: 12 hours dark photoperiod. They were fed with 3 or 4
Ceriodaphnia silvestrii neonates per hydra, three times in the week, and recipient media were changed twice a week. The occurrence of other microorganisms from which hydras could be fed, such as protozoans or rotifers, was checked periodically throughout the experiment, by examining subsamples under the microscope. No other organisms were found.

In the individual growth experiment, each replicate had one hydra with a single bud. The animal was examined daily and measured under a stereomicroscope. From the moment the bud separated from the mother polyp, the length and diameter of this knew hydra were measured once a day until it had grown and begun to reproduce, by giving rise to a bud. From then on, the length and diameter of the new bud were measured daily until it, in turn, separated from the mother polyp. Organisms were carefully taken from the experimental flasks using a large mouth pipette and placed in excavated slides with drops of water. Total length and diameter were measured with a micrometer, under a stereomicroscope, for the whole extended hydra column from oral to the aboral region. The generation time of the species was defined as the time elapsed between the separation of a bud from its mother hydra, to the production and the separation of its first bud.

The growth-curve for the body length of Hydra viridissima was obtained by applying Von Bertalanffy's model (Bertalanffy, 1938), the parameters of which were calculated by using the Ford-Walford transformation (Walford, 1946):

$\mathrm{L}_{\mathrm{t}}=\mathrm{L} \infty\left[1-\mathrm{e}^{-\mathrm{k}(\mathrm{t}-\mathrm{to})}\right]$

where: $\mathrm{L}_{\mathrm{t}}=$ length in one determined time $\mathrm{t}(\mathrm{mm})$; $\mathrm{L} \infty=$ maximum length which, on average, the organisms can reach, being the asymptotic limit of the curve; $\mathrm{e}=$ base of natural logarithm; $\mathrm{k}=$ growth-rate constant; to = parameter related to the initial length of individuals at birth (Lo), expressed in days.

Each replicate population growth test started with a population of three full-grown hydras. The individuals were inspected every 2-3 days and counted under a stereomicroscope. These experiments continued for 65 days.

The instantaneous natural growth-rate was calculated with the following differential equation (Odum, 1988): $\mathrm{dN} / \mathrm{dt}=\mathrm{rN}$.

This may be integrated to give:

$\mathrm{Nt}=\mathrm{N}_{0} \mathrm{e}^{\mathrm{rt}}$

where: $\mathrm{Nt}=$ number of organisms at time $\mathrm{t} ; \mathrm{N}_{0}=$ initial number of organisms; $\mathrm{t}=$ the duration of the experiment; $\mathrm{r}=$ intrinsic population growth-rate; $\mathrm{e}=$ base of natural logarithm.

The parameter $r$ can be considered an instantaneous coefficient of population growth (Odum, 1988), and is calculated by means of the following expression:

$\mathrm{r}=(\ln \mathrm{Nt}-\ln \mathrm{N} 0) / \mathrm{t}$ 
From this coefficient, the population doubling-time $\left(\mathrm{t}_{2}\right)$ can be obtained by: $\mathrm{t}_{2}=\ln 2 / \mathrm{r}$.

\section{Results}

The individual length data for Hydra viridissima are plotted in Figure 1, where all the points shown for one day represent replicates. The curve has been fitted to the data, assuming the Von Bertalanffy model for individual growth. Length data were collected from the time a new hydra separated from the mother polyp until the appearance of its first bud.

The fitted curve follows the equation:

$\mathrm{L}_{\mathrm{t}}=2.53\left[1-\mathrm{e}^{-0.43(\mathrm{t}+1.47)}\right]$

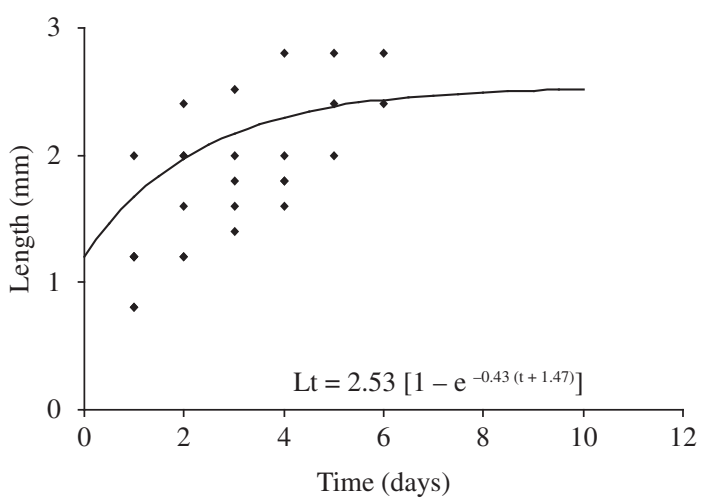

Figure 1. Individual growth curve of Hydra viridissima cultured in reconstituted water at $20 \pm 2{ }^{\circ} \mathrm{C}$, in a 12 hours light: 12 hours dark photoperiod, with a diet of neonates of the cladoceran Ceriodaphnia silvestrii. Data points for each day represent one or more of the seven replicates that survived until the end of the experiment.
Thus, the average maximum length reached by hydras was $2.53 \mathrm{~mm}(\mathrm{~L} \infty)$ and the daily growth-rate was $0.43(\mathrm{k})$, that is the columns lengthened by about $40 \%$ every day.

It was found that soon after having separated from the mother polyp, the new hydras were $1.2 \pm 0.4 \mathrm{~mm}$ long and $0.09 \pm 0.02 \mathrm{~mm}$ in diameter, at $5 \pm 1.77$ days after separation, on average, they attained a mean length of $2.22 \pm 0.4 \mathrm{~mm}$ and a diameter of $0.12 \pm 0.02 \mathrm{~mm}$, and began to form buds (Table 1).

The buds were also measured, daily, from their first appearance until they separated from the mother hydra. Starting with a mean length $0.28 \pm 0.12 \mathrm{~mm}$ and diameter $0.12 \pm 0.02 \mathrm{~mm}$, they grew, in $1.6 \pm 0.5$ days on average, to a mean length $0.52 \pm 0.2 \mathrm{~mm}$ and diameter $0.14 \pm 0.03 \mathrm{~mm}$ and then separated from the mother polyp (Table 2). Thus, the mean generation time of Hydra viridissima in the laboratory conditions described was $6.6 \pm 1.5$ days.

An exponential curve has been fitted to the population growth data obtained for Hydra viridissima in Figure 2. The average rate of population growth of this species can be obtained from this curve, which is described by the following equation, with a coefficient of determination $\left(\mathrm{R}^{2}\right)$ of 0.9511 :

$\mathrm{Nt}=5.785 \mathrm{e}^{0.0468 \mathrm{t}}$

Hence, the instantaneous rate constant for population growth (r) is of 0.0468 by the end of the 65-day experiment, each replicate (initially 3 hydras) had grown, on average, to $109.1 \pm 26.44$ hydras (Table 3 ). The average doubling time for the population of Hydra viridissima culture in the laboratory, was calculated from $\mathrm{r}$ as $14.8 \pm 2.63$ days.

Table 1. Individual length (L) and diameter (D) of Hydra viridissima cultured in the laboratory, mean values and its respective standard deviations (SD) and range of variation, from the moment a bud detached from parent polyp until the appearance of its first bud (*).

\begin{tabular}{|c|c|c|c|c|c|c|c|c|c|c|}
\hline \multirow{2}{*}{$\begin{array}{l}\text { Time } \\
\text { (days) }\end{array}$} & \multirow{2}{*}{$\begin{array}{c}\text { Parameter } \\
(\mathbf{m m})\end{array}$} & \multicolumn{7}{|c|}{ Replicates } & \multirow[t]{2}{*}{ Mean \pm SD } & \multirow[t]{2}{*}{ Range } \\
\hline & & 1 & 2 & 3 & 4 & 5 & 6 & 7 & & \\
\hline \multirow{2}{*}{1} & $\mathrm{~L}$ & 1.2 & 1.2 & 1.2 & 0.8 & 1.2 & 2.0 & 0.8 & $1.2 \pm 0.40$ & $0.8-2.0$ \\
\hline & $\mathrm{D}$ & 0.08 & 0.12 & 0.08 & 0.08 & 0.08 & 0.12 & 0.08 & $0.09 \pm 0.02$ & $0.08-0.12$ \\
\hline \multirow{2}{*}{2} & $\mathrm{~L}$ & 1.2 & 2.0 & 2.0 & 2.4 & 1.6 & $2.48 *$ & 1.2 & $1.82 \pm 0.52$ & $1.2-2.4$ \\
\hline & $\mathrm{D}$ & 0.08 & 0.12 & 0.12 & 0.08 & 0.08 & $0.12 *$ & 0.12 & $0.10 \pm 0.02$ & $0.08-0.12$ \\
\hline \multirow{2}{*}{3} & $\mathrm{~L}$ & 1.6 & $2.0 *$ & 2.0 & 2.52 & 1.8 & - & 1.4 & $1.88 \pm 0.38$ & $1.4-2.52$ \\
\hline & $\mathrm{D}$ & 0.08 & $0.12 *$ & 0.12 & 0.08 & 0.08 & - & 0.12 & $0.10 \pm 0.02$ & $0.08-0.12$ \\
\hline \multirow{2}{*}{4} & $\mathrm{~L}$ & 1.8 & - & 2.0 & 2.8 & 1.8 & - & 1.6 & $2.0 \pm 0.46$ & $1.6-2.8$ \\
\hline & $\mathrm{D}$ & 0.12 & - & 0.12 & 0.08 & 0.08 & - & 0.16 & $0.11 \pm 0.03$ & $0.08-0.16$ \\
\hline \multirow{2}{*}{5} & $\mathrm{~L}$ & $1.8 *$ & - & 2.0 & 2.8 & 2.4 & - & $2.0 *$ & $2.2 \pm 0.40$ & $1.8-2.8$ \\
\hline & $\mathrm{D}$ & $0.12 *$ & - & 0.12 & 0.08 & 0.08 & - & $0.16^{*}$ & $0.11 \pm 0.03$ & $0.08-0.16$ \\
\hline \multirow{2}{*}{6} & $\mathrm{~L}$ & - & - & $2.0 *$ & 2.8 & 2.4 & - & - & $2.4 \pm 0.40$ & $2.0-2.4$ \\
\hline & $\mathrm{D}$ & - & - & $0.12 *$ & 0.12 & 0.08 & - & - & $0.10 \pm 0.02$ & $0.08-0.12$ \\
\hline \multirow{2}{*}{7} & $\mathrm{~L}$ & - & - & - & $3.0^{*}$ & $2.4^{*}$ & - & - & $2.7 \pm 0.42$ & $2.4-3.0$ \\
\hline & $\mathrm{D}$ & - & - & - & $0.12 *$ & $0.08 *$ & - & - & $0.10 \pm 0.03$ & $0.08-0.12$ \\
\hline
\end{tabular}


Table 2. Individual length (L) and diameter (D) of Hydra viridissima cultured in the laboratory, mean values and its respective standard deviations (SD) and range of variation, from the moment a bud started to develop until it detached from parent polyp (*).

\begin{tabular}{ccccccccccc}
\hline \multirow{2}{*}{$\begin{array}{c}\text { Time } \\
(\text { days })\end{array}$} & $\begin{array}{c}\text { Parameter } \\
(\mathbf{m m})\end{array}$ & \multicolumn{1}{c}{$\mathbf{1}$} & $\mathbf{2}$ & $\mathbf{3}$ & $\mathbf{4}$ & $\mathbf{5}$ & $\mathbf{6}$ & $\mathbf{7}$ & Mean \pm SD & Range \\
\cline { 3 - 10 } 1 & $\mathrm{~L}$ & 0.12 & 0.2 & 0.16 & $0.4^{*}$ & $0.4^{*}$ & 0.4 & $0.3^{*}$ & $0.28 \pm 0.12$ & $0.12-0.4$ \\
& $\mathrm{D}$ & 0.12 & 0.08 & 0.12 & $0.12^{*}$ & $0.12^{*}$ & 0.12 & $0.16^{*}$ & $0.12 \pm 0.02$ & $0.08-0.16$ \\
2 & $\mathrm{~L}$ & $0.8^{*}$ & $0.4^{*}$ & $0.6^{*}$ & - & - & $0.8^{*}$ & - & $0.65 \pm 0.19$ & $0.4-0.8$ \\
& $\mathrm{D}$ & $0.12^{*}$ & $0.16^{*}$ & $0.2 *$ & - & - & $0.12 *$ & - & $0.15 \pm 0.03$ & $0.12-0.2$ \\
\hline
\end{tabular}

Table 3. Mean population sizes, standard deviations (SD) and range, at different time intervals for Hydra viridissima cultures, in the laboratory, during 65 day period.

\begin{tabular}{ccc}
\hline Time (days) & Mean \pm SD & Range \\
\hline 5 & $6.9 \pm 2.54$ & $3-10$ \\
15 & $17.5 \pm 8.53$ & $6-33$ \\
25 & $20.9 \pm 9.42$ & $8-36$ \\
35 & $26.7 \pm 11.61$ & $12-47$ \\
45 & $48.5 \pm 16.80$ & $30-83$ \\
55 & $72.8 \pm 17.56$ & $38-99$ \\
65 & $109.1 \pm 26.44$ & $60-145$ \\
\hline
\end{tabular}

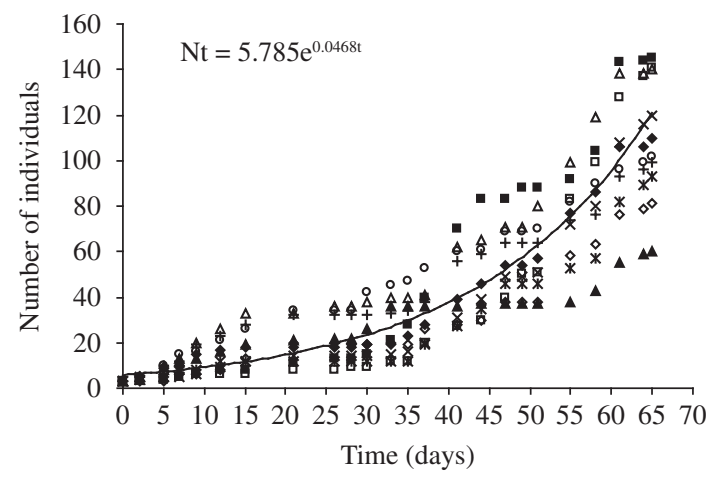

Figure 2. Population growth curve of Hydra viridissima cultured in reconstituted water at $20 \pm 2{ }^{\circ} \mathrm{C}$, in a 12 hours light: 12 hours dark photoperiod, fed on neonates of the cladoceran Ceriodaphnia silvestrii. Each symbol represents an experimental replicate.

\section{Discussion}

Sugiyama and Fujisawa (1979) cultured Hydra magnipapillata, taken from 10 different sites in Japan, at $18 \pm 1{ }^{\circ} \mathrm{C}$, feeding them with Artemia salina. They reported a mean generation time of $8.3 \pm 3.22$ days, somewhat longer than that exhibited by Hydra viridissima in the present study ( $6.6 \pm 1.5$ days) at the temperature of $20 \pm 2{ }^{\circ} \mathrm{C}$.

According to Slobodkin et al. (1991), the length of the column of individual hydras varies appreciably within a species, depending on the culture conditions, such as food and temperature, and also on genetic factors. Bossert and Dunn (1986) noted that hydras of the same species, collected at various sites but maintained in laboratory cultures under the same conditions of temperature, light and food, varied in body size. They collected Hydra viridissima polyps from 3 different sites and cultured them in the laboratory at $20{ }^{\circ} \mathrm{C}$, feeding them on Artemia salina. Organisms originating from each site exhibited a different length: $3.75 \pm 0.25 \mathrm{~mm}$, $3.06 \pm 0.13 \mathrm{~mm}$ and $2.29 \pm 0.11 \mathrm{~mm}$.

Regarding the intrinsic population growth-rate, Hydra viridissima exhibited a value $\mathrm{r}=0.0468$, with coefficient of determination $\mathrm{R}^{2}=0.9511$.

Under outdoor conditions, variations of the rate of increase of a population (r) are observed, caused both by intrinsic factors (age structure and genetic make-up of the population) and changing environmental conditions. In controlled conditions in the laboratory, where limiting factors that may affect the population have been eliminated, it is possible to determine the natural capacity for population growth with given combinations of experimental factors, such as temperature, quality and quantity of food, etc. (Krebs, 1986).

Sugiyama and Fujisawa (1979) reported a variation in the intrinsic population growth-rate of Hydra magnipapillata among specimens collected at different sites, obtaining values of $\mathrm{r}$ from 0.06 a 0.26 .

It will have been noted that the same species may exhibit quite different intrinsic population growth-rates, since the culture and stock maintenance conditions generally vary, as do the temperature and diet during experiments. As the process of growth is specific to each type of organism, it is important to establish the pattern of growth of a species, in order to try and explain the relation between its growth-rates and its habitat (Nikolski, 1963).

The natural intrinsic rate of increase observed for Hydra viridissima was 0.0468 a value of $r$ similar to the lowest found by Sugiyama and Fujisawa (1979) for Hydra magnipapillata (0.06). Differences between population growth-rates of species can be explained partly by their genomes that result in different life-cycle traits and also because the species were not grown under identical conditions.

Knowing the value of $r$, it is possible to determine the doubling time for a population, by dividing the natural $\log$ of $2(\ln 2)$ by the value of $r($ Odum, 1988). The Hydra viridissima population grown in the laboratory in this study had a mean doubling time of $14.8 \pm 2.63$ days. 
For Hydra magnipapillata, Sugiyama and Fujisawa (1979) found doubling times varying from 3 to 10 days, using standard hydra culturing procedures. Habetha et al. (2003) analyzed the population growth of Hydra viridissima given three different food treatments (fed daily; once a week and once a fortnight on Artemia salina). They observed that the population fed daily doubled in 3 days; those fed once a week, in 14 days, and those fed once a fortnight, in 31 days. Therefore, the doubling time of the Hydra viridissima population studied here was similar to that found by those authors for hydras fed once a week on Artemia salina.

According to Bosh and David (1984), the growth rate of Hydra is closely related to the feeding conditions of the organisms. Possibly, the doubling time found in the present study would be shorter if the animals were fed daily. Therefore, it would be interesting to test different food items to find the food preferences of this species, as well as to test the maximum ingestion rates, in order to establish the best culturing conditions, and hence the highest population growth rate.

It was concluded that once an adequate culture medium and food are found it is relatively easy to culture Hydra viridissima in the laboratory. For the conditions established, the species performed well, reproducing quickly and consequently having a short generation time. However, further studies may improve the culture conditions, allowing the standardization of culture procedures, since this species is a potential test-organism for bioassays.

Acknowledgements - The authors thank CAPES/CNPq for the scholarship awarded to the first author, and to the BIOTA/ FAPESP and PRONEX/PROBIO (CNPq/MMA) programs for research funding.

\section{References}

ASSOCIAÇÃO BRASILEIRA DE NORMAS TÉCNICAS - ABNT. NBR 12713, 2004. Ecotoxicologia aquática Toxicidade aguda - Método de ensaio com Daphnia spp (Cladocera, Crustacea). 21 p.

BERTALANFFY, L. Von., 1938. A quantitative theory of organic growth. Hum. Biol., vol. 10, no. 2, p. 181-213.

BOSCH, TC. and DAVID, CN., 1984. Growth regulation in Hydra: Relationship between epithelial cell cycle length and growth rate. Dev. Biol., vol. 104, no. 1, p. 161-171.

BOSSERT, P. and DUNN, KW., 1986. Regulation of intracellular algae by various strains of the symbiotic Hydra viridissima. $J$. Cell. Sci., vol. 85, no. 1, p. 187-195.

CORDERO, EH., 1939. Observaciones sobre algunas especies Sud-Americanas del género Hydra. I. Hydra en el Nordeste del Brazil. Anais Acad. Bras. Ci., vol. 11, no. 4, p. 335-340.

DOUGLAS, AE., 1995. Symbiotic Interactions. Oxford: Oxford University Press. 148 p.

HABETHA, M., ANTON-ERXLEBEN, F., NEUMANN, K. and BOSCH, TCG., 2003. The Hydra viridis/Chlorella simbiosis. Growth and sexual differentiation in polyps without symbionts. Zoology, vol. 106, no. 2, p. 101-108.
HOLSTEIN, T., 1995. Cnidaria: Hydrozoa. In BRAUER, A., SCHWOERBEL, J. and ZWICK, P. (coords.), Süsswasserfauna von Mitteleuropa. Stuttgart: Gustav Fischer Verlag. p. 1-110.

KELTY, MO. and COOK, CB., 1976. Survival during starvation of symbiotic, aposymbiotic, and non-symbiotic Hydra. In Mackie, GO. (ed.). Coelenterate Ecology and Behavior. New York: Plenum Press. p. 409-414.

KREBS, CJ., 1986. Ecologia. Análisis experimental de la distribuición y abundancia. 3. ed. Madrid: Ediciones Pirámide. $172 \mathrm{p}$.

LENHOFF, HM. and MUSCATINE, L., 1963. On the role of algae symbiotic with Hydra. Science, vol. 142, no. 3594, p. $956-958$.

MUSCATINE, L., 1965. Symbiosis of Hydra and algae. III Extracellular products of the algae, Comp. Biochem. Physiol., vol. 16, no. 1, p. 77-92.

MUSCATINE, L., 1974. Endosymbiosis of cnidarians and algae, In LENHOFF, HM. and MUSCATINE, L. (eds.), Coelenterate Biology: Reviews and New Perspectives. New York: Academic Press. p. 359-395.

NIKOLSKI, GV., 1963. The ecology of fishes. London and New York: Academic Press. 351 p.

ODUM, EP., 1988. Ecologia. Rio de Janeiro: Ed. Guanabara Koogan S. A. 434 p.

PENNAK, RW., 1953. Freshwater Invertebrates of the United States. N.Y.: The Ronald Press Company, cap. 4, p. 98-113.

ROFFMAN, B. and LENHOFF, HM., 1969. Formation of polysaccharides by Hydra from substrates produced by their endosymbiotic algae. Nature, vol. 221, no. 5178, p. 381-382.

SILVEIRA, FL. and SCHLENZ, E., 1999. Cnidários. In ISMAEL, D., VALENTE, WC., TUNDISI, TM. and O. Rocha (eds.), Invertebrados de Água Doce. S. Paulo/SP: FAPESP, vol. $4.176 \mathrm{p}$.

SILVEIRA, FL., GOMES, CS. and SILVA, Z. DE S., 1997. New species of Hydra Linnaeus, 1758 (Cnidaria, Hydrozoa) from southeastern Brazil. Boletim do Museu Nacional, Zoologia, no. 373. p. 1-15.

SLOBODKIN, LB., BOSSERT, P., MATESSI, C. and GATTO, M., 1991. A review of some physiological and evolutionary aspects of body size and bud size of Hydra. Hydrobiologia, vol. $216 / 217$, no. 1 , p. $377-382$.

SUGIYAMA, T. and FUJISAWA, T., 1979. Genetic analysis of developmental mechanisms in Hydra VII. Statistical analyses of developmental-morphological characters and cellular compositions. Develop., Growth and Differ., vol. 21, no. 4, p. 361-375.

TROTTIER, S., BLAISE, C., KUSUI, T. and JOHNSON, EM., 1997. Acute toxicity assessment of aqueous samples using a microplate-based Hydra attenuata assay. Environm. Toxicol. Water. Qual., vol. 12, no. 3, p. 265-271.

WALFORD, LA., 1946. A new graphic method of describing the growth animals. Biol. Bull., vol. 90, no. 2, p. 141-147.

WOLLE, LC., 1978. Hydra intermedia sp. nov. and notes on Chlorohydra viridissima (Pallas) (Cnidaria). Bolm. Zool. Univ. S. Paulo, vol. 3, p. 143-152. 